\title{
1’000’000 Amperes Deram Cell
}

\author{
Rene V. Kaenel*, Jacques Antille, \\ Louis Bugnion and Laure V. Kaenel \\ Kan-nak S.A.
} PO Box 477, CH-3960, Route de Sion 35, Sierre, Switzerland

Received 26.02.2016, received in revised form 18.04.2016, accepted 20.05.2016

The aluminum industry is constantly looking at reducing the production cost. During the last three decades it has mainly been achieved by the economy of scale consisting in increasing the cell dimensions allowing for higher current and therefore increasing the plant production and productivity. This paper presents under which conditions a step change can be achieved without increasing the shell dimensions. The design of a cell of the future is discussed in term of voltage distribution, heat loss, energy saving, productivity and environmental consequences.

Keywords: High productivity, Low specific energy, Low emissions.

Citation: Kaenel R.V., Antille J., Bugnion L., Kaenel L.V. 1’000’000 amperes deram cell, J. Sib. Fed. Univ. Eng. technol., 2016, 9(6), 802-810. DOI: 10.17516/1999-494X-2016-9-6-802-810.

\section{Электролизер мечты: 1’000’000 ампер}

Rene V. Kaenel, Jacques Antille,
Louis Bugnion, Laure V. Kaenel Kan-nak S.A.

PO Box 477, CH-3960, Route de Sion 35, Sierre, Щвейцария

\begin{abstract}
Алюминиевая промышленность постоянно изыскивает способы снижения производственных затрат. За последние три десятилетия это было достигнуто за счет экономии масштабов, при этом размеры электролизера были увеличены, что позволило применять более высокую силу тока для увеличения объемов производства и производительности. В статье обсуждается вопрос, при каких условиях можно достичь качественного изменения без увеличения размеров кожуха. Обсуждается конструкиия электролизера будущеего с точки зрения распределения напряжения, тепловых потерь, экономии энергии, производительности и экологических последствий.
\end{abstract}

Ключевые слова: высокая производительность, низкий расход энергии, низкий уровень выбросов.

(C) Siberian Federal University. All rights reserved

* Corresponding author E-mail address: rene.vonkaenel@kannak.ch 


\section{Introduction}

During the last three decades, the line current in aluminium reduction plants has increased considerably and has reached $600 \mathrm{kA}$. During the same period all smelters have been active at increasing the productivity in their existing shell by increasing the anode size and the anode current density. This was achieved by better cathode and collector bars designs sometimes combined with busbars modifications to improve the cell magneto-hydrodynamic stability. A better magneto-hydrodynamic cell state allows decreasing the anode to cathode distance (ACD) needed for achieving the right thermal balance. If the cell productivity is expressed as tons produced per year and square meter inside a given shell, the increase have proven to be in the range of 10 to $30 \%$. In the best case it has reached $80 \%$ depending on the initial state of the cell technology and level of optimization. During the same period the current efficiency has also improved and the best technologies achieve results close to $96 \%$. When analyzing the evolution of the specific energy consumption $(E)$, a decrease from above $14 \mathrm{kWh} / \mathrm{kg}$ to $13 \mathrm{kWh}$ and lower was achieved in many smelters. The theoretical energy consumption can be expressed as:

$$
E=1.431 / \eta+4.915[\mathrm{kWh} / \mathrm{kg}]
$$

where $\eta$ is the current efficiency. The energy efficiency is the ratio of the needed energy to the used energy. The energy efficiency of the Hall-Héroult process is low as shown in Table 1. It was increased from about $43 \%$ to $48 \%$ over 30 years and has hardly reached $50 \%$ in the best cases.

It is reasonable to ask ourselves what can be done to further improve the plant productivity. Should we double the length of the cell to double the current? Would it help at increasing the energy efficiency and current efficiency? Knowing that today high amperage cells are in the range of 20 meters in length, doubling the length does not seem to be reasonable. Increasing the width appears also as a challenge for the magneto-hydrodynamic cell stability and for the anode length and weight. Not to be forgotten, for every kilo of aluminum produced more than one kilo carbon-dioxide and about hundred grams of carbon monoxide are produced. With sixty millions tons of aluminum produced every year it is not negligible.

So what can be done?

Table 1. Hall-Héroult process energy efficiency

\begin{tabular}{|c|c|c|}
\hline Current efficiency, $\%$ & Specific energy, $\mathrm{kWh} / \mathrm{kg}$ & Energy efficiency, $\%$ \\
\hline 94 & 6.26 & 100 \\
\hline 94 & 15.00 & 41.7 \\
\hline 94 & 14.00 & 44.7 \\
\hline 94 & 13.00 & 48.2 \\
\hline 94 & 12.00 & 52.2 \\
\hline 94 & 11.00 & 56.9 \\
\hline 94 & 10.00 & 62.6 \\
\hline
\end{tabular}




\section{The cell of the future}

The cell of the future should satisfy our dreams, however realistic dreams, such as:

- High productivity: more than double than today

- Low specific energy consumption: lower than $12 \mathrm{kWh} / \mathrm{kg}$

- High current efficiency: higher than $95 \%$

- High volume of bath/kA: higher chemical stability

- Low bath temperature: higher current efficiency

- Lower energy

Is it a dream or does it make sense?

How can we achieve these performances?

The authors see no possibilities to achieve such a dream with the existing carbon anodes, but, when using metallic anodes [1], many possibilities of redesigning the cell are coming up. In this paper the authors have analyzed what looks very promising to their point of view. Table 2 challenges the parameters of a dreaming cell to an existing cell technology.

The table speaks by itself but let us comment the important parameters. The productivity is increased by a factor 2.8 . This was never achieved before. The specific energy consumption is lower than $12 \mathrm{kWh} / \mathrm{kg}$. This is remarkable and contradicts many beliefs stating that the "inert anode" has to pay one extra volt and therefore will produce with about $3 \mathrm{kWh} / \mathrm{kg}$ increase of specific energy. The result is of course linked to the design shown after. The current efficiency is shown as $96 \%$. This cannot be calculated with accuracy but is more an assumption linked to the fact that the anode to cathode distance is constant in the dream cell and the amount of bath is more than ten times bigger for every $\mathrm{kA}$ in the

Table 2. Comparison between an existing technology and "A dream cell"

\begin{tabular}{|c|c|c|c|}
\hline \multicolumn{4}{|c|}{ How to make a dream come true 1'000'000 A cell } \\
\hline & \multirow[b]{2}{*}{ Unit } & Reference & Vision \\
\hline & & $\begin{array}{l}\text { Modern Hall-Heroult } \\
\text { technology }\end{array}$ & $\begin{array}{c}\text { Future Hall-Heroult } \\
\text { technology }\end{array}$ \\
\hline \multicolumn{4}{|c|}{ Operating parameters } \\
\hline Productivity & $\%$ & 100 & 278 \\
\hline Amperage & $\mathrm{kA}$ & 360.0 & 1000.0 \\
\hline Specific energy consumption & $\mathrm{kWh} / \mathrm{kg} \mathrm{Al}$ & 12.84 & 11.73 \\
\hline Gross volt & $\mathrm{V}$ & 4.05 & 3.78 \\
\hline Current efficiency & $\%$ & 94.0 & 96.0 \\
\hline Production & $\mathrm{kg} \mathrm{Al} /$ pot-day & 2726 & 7732 \\
\hline \multicolumn{4}{|c|}{ Geometry } \\
\hline Cell length & $\mathrm{m}$ & 15 & 15 \\
\hline Cell width & $\mathrm{m}$ & 4.4 & 4.4 \\
\hline Cell cavity & $\mathrm{m}$ & 1.3 & 1.3 \\
\hline Anode width & $\mathrm{mm}$ & 650 & 650 \\
\hline Anode length & $\mathrm{mm}$ & 1600 & 4480 \\
\hline Number of anodes & & 40 & 40 \\
\hline Anodic current density (geometry) & $\mathrm{A} / \mathrm{cm}^{2}$ & 0.865 & 0.859 \\
\hline
\end{tabular}


cell. The bath chemistry and bath temperature that are strongly correlated must therefore remain much more stable than today for the benefit of the current efficiency. Last but not least, the operating temperature of the dream cell is $900{ }^{\circ} \mathrm{C}$ in our model which is also in favor of higher current efficiency. Each point will be further highlighted. The cell dimensions are kept fully unchanged and so are the anode dimensions. Only the length of the anode is increased $1600 \mathrm{~mm}$ to $4480 \mathrm{~mm}$. How is that possible?

Figure 1 shows the reference carbon anode. Figure 2 shows how the metallic anode has a surface of 2.8 times the surface of the carbon anode. Figure 3 shows the metallic anode. This is where the miracle takes place. Due to the dimension stability of the anodes and the high conductivity of metallic anodes, the geometry can be fully revisited. The average current density is almost kept constant but the electrical circuit is fully revisited. The average anode current density is $0.865 \mathrm{~A} / \mathrm{cm}^{2}$ for the carbon. The cell current is $0.865 \cdot 160 \cdot 65 \cdot 40=360$ '000 A. For the metallic anode the surface is multiplied by 2.8 so the current can be 1 '000'000 A.

\section{Cell thermal-electrical model}

Table 3 summarizes the voltage breakdown of both technologies. The external voltage is assumed to be the same for both. This can be achieved by using adequate busbars sections. The anode voltage drop is $160 \mathrm{mV}$ lower for the metallic anode due to the higher conductivity of the assumed Ni-Fe metallic structure compared to the carbon anode. No anode effects are expected to

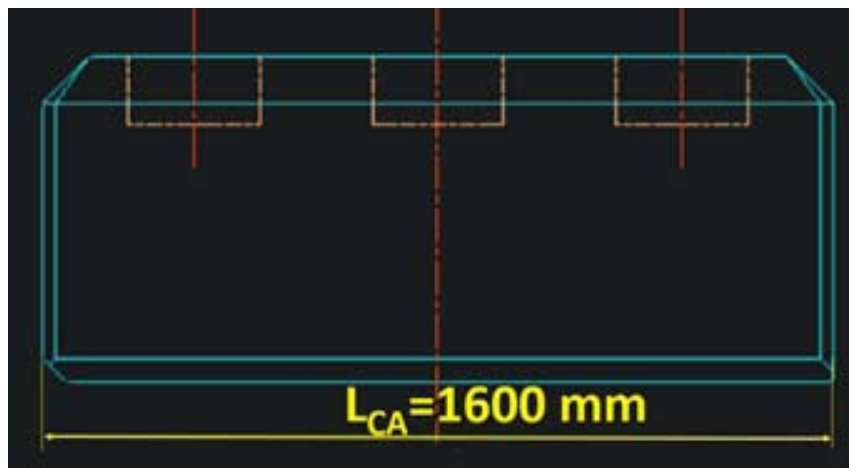

Fig. 1. Carbon anode

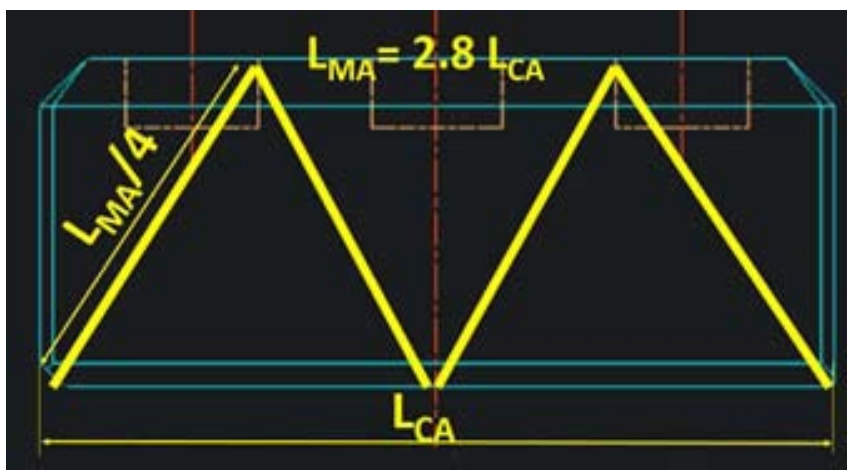

Fig. 2. Concept for the surface for the metallic anode 


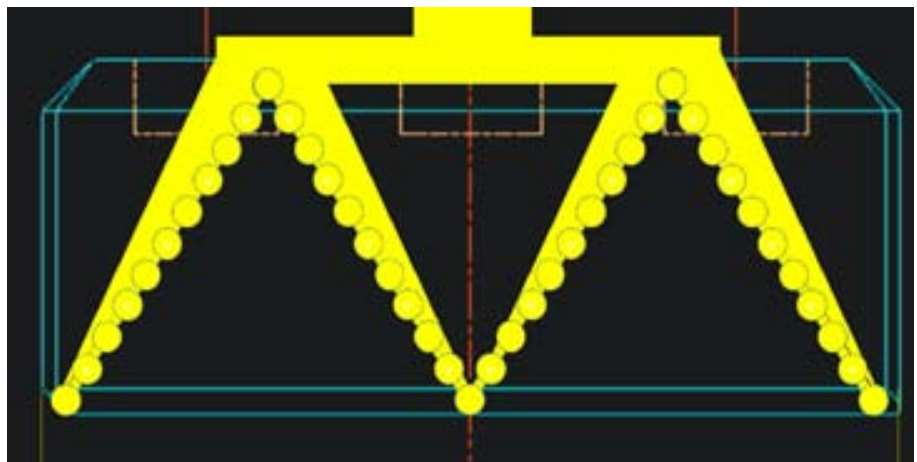

Fig. 3. Example of metallic anode geometry

Table 3. Voltage breakdown

\begin{tabular}{|l|c|c|c|}
\hline \multicolumn{4}{|c|}{ How to make a dream come true 1'000'000 A cell } \\
\hline \multirow{2}{*}{ Voltage breakdown } & Unit & Reference & Vision \\
\cline { 3 - 4 } & & $\begin{array}{c}\text { Modern Hall-Heroult } \\
\text { technology }\end{array}$ & $\begin{array}{c}\text { Future Hall-Heroult } \\
\text { technology }\end{array}$ \\
\hline External & V & 0.230 & \\
\hline Busbars + Beam to anode & & \multicolumn{2}{c|}{} \\
\hline Internal & V & 0.260 & 0.100 \\
\hline Anode voltage & $\mathrm{V}$ & 0.005 & 0.000 \\
\hline Anode Effects + Anode Change & $\mathrm{V}$ & 0.197 & 0.000 \\
\hline Gas bubbles / Thonstad-Vogt & $\mathrm{V}$ & 1.248 & 2.250 \\
\hline Decomposition voltage & $\mathrm{V}$ & 0.512 & 0.000 \\
\hline Anodic reaction overvoltage & $\mathrm{V}$ & 0.060 & 0.063 \\
\hline Anodic concentration overvoltage & $\mathrm{V}$ & 0.095 & 0.090 \\
\hline Cathodic overvoltage & $\mathrm{V}$ & 0.252 & 0.200 \\
\hline Cathode Voltage Drop (CVD) & $\mathrm{V}$ & 1.191 & 0.847 \\
\hline Ubath & $\mathrm{cm}$ & 3.47 & 2.03 \\
\hline ACD with bubbles & $\mathrm{dm} / \mathrm{kA}$ & 6.4 & 39.6 \\
\hline Bath volume per kA & $\mathrm{V}$ & 4.05 & 3.78 \\
\hline Gross volt & & \\
\hline
\end{tabular}

take place with the metallic anode and the bubbles voltage is considered as negligible due to the anode geometry. The decomposition voltage of the metallic anode is about $1 \mathrm{~V}$ higher. This is the cost of producing oxygen instead of carbon dioxide. The energy needed to produce the metallic anode will also be lower than for the carbon anode and this is not considered in our energy balance. The fixed anode geometry will allow to operate at lower anode to cathode distance (ACD). In this example a distance of $2 \mathrm{~cm}$ was calculated in order to produce a reasonable heat loss for the cell that is compatible with a good ledge thickness.

Table 4 shows the energy aspects of both technologies. It can be observed that the global energy efficiency is better, the internal heat of both technologies is very similar. This means that a similar 
thermal equilibrium can be found leading to a similar ledge shape. The specific energy of the metallic anode technology is $11.73 \mathrm{kWh} / \mathrm{kg}$ which is lower than any standard Hall-Héroult existing cell. This shows that metallic anodes can be competitive to the carbon anodes when used with the Hall-Héroult process if the cell design is adequate.

Table 5 shows an example of bath that could be used for both technologies. The use of lithium is important to decrease the bath resistivity to compensate for the addition of potassium fluoride needed

Table 4. Energy aspects

\begin{tabular}{|l|c|c|c|}
\hline \multicolumn{4}{|c|}{ How to make a dream come true 1'000'000 A cell } \\
\hline \multicolumn{2}{|c|}{ Unit } & Reference & Vision \\
\cline { 2 - 4 } & & $\begin{array}{c}\text { Modern Hall-Heroult } \\
\text { technology }\end{array}$ & $\begin{array}{c}\text { Future Hall-Heroult } \\
\text { technology }\end{array}$ \\
\hline \multicolumn{2}{|c|}{ Specific energy Hall-Heroult process } \\
\hline External heat & $\mathrm{kWh} / \mathrm{kg}$ & 0.73 & 0.71 \\
\hline Internal heat & $\mathrm{kWh} / \mathrm{kg}$ & 5.67 & 1.76 \\
\hline Energy to produce metal & $\mathrm{kWh} / \mathrm{kg}$ & 6.44 & 9.26 \\
\hline Total & $\mathrm{kWh} / \mathrm{kg}$ & 12.84 & 11.73 \\
\hline Energy efficiency (theoretical/used energy) & $\%$ & 48.8 & 53.6 \\
\hline \multicolumn{2}{|c|}{ Power Hall-Heroult process } & 82.8 & 230.0 \\
\hline External heat & $\mathrm{KW}$ & 644.2 & 566.3 \\
\hline Internal heat & $\mathrm{KW}$ & 731 & 2984 \\
\hline Energy to produce metal & $\mathrm{KW}$ & 1458 & 3780 \\
\hline Total & $\mathrm{KW}$ & & \\
\hline
\end{tabular}

Table 5: Bath properties

\begin{tabular}{|c|c|c|c|}
\hline \multicolumn{4}{|c|}{ How to make a dream come true 1'000'000 A cell } \\
\hline & & Reference & Vision \\
\hline & & $\begin{array}{l}\text { Modern Hall-Heroult } \\
\text { tehcnology }\end{array}$ & $\begin{array}{c}\text { Future Hall-Heroult } \\
\text { technology }\end{array}$ \\
\hline \multirow[t]{12}{*}{ Bath chemistry } & $\% \mathrm{AlF}_{3}$ excess & 11.5 & 11.5 \\
\hline & $\% \mathrm{CaF}_{2}$ & 5.0 & 6.0 \\
\hline & $\% \mathrm{Al}_{2} \mathrm{O}_{3}$ & 2.5 & 4.0 \\
\hline & $\% \mathrm{LiF}$ & 0.0 & 4.5 \\
\hline & $\% \mathrm{MgF}_{2}$ & 0.3 & 0.5 \\
\hline & $\% \mathrm{KaF}$ & 0.0 & 5.0 \\
\hline & Ratio & 1.106 & 1.057 \\
\hline & Bain $\mathrm{T}$ & 965 & 900 \\
\hline & $\mathrm{Al}_{2} \mathrm{O}_{3} \_\mathrm{SAT}$ & 8.33 & 4.52 \\
\hline & Liquidus $\mathrm{T}$ & 959 & 893 \\
\hline & Superheat & 5.7 & 7 \\
\hline & Bath resist & 0.463 & 0.485 \\
\hline
\end{tabular}


to decrease the operating temperature. As a result both technologies have about the same bath electrical conductivities.

To demonstrate the feasibility a full three dimensional model was realized based on a $360 \mathrm{kA}$ cell. The coupled thermal-electrical problem was solved. Figure 4 shows the cell geometry.

Figure 5 shows a vertical section through the cell showing the anode shape, the graphite wettable cathode and the level of the liquid metal before tapping.

Figure 6 shows $1 / 4$ anode geometry. This geometry could further be improved to minimize the voltage drop but this was not considered in the scope of this paper.

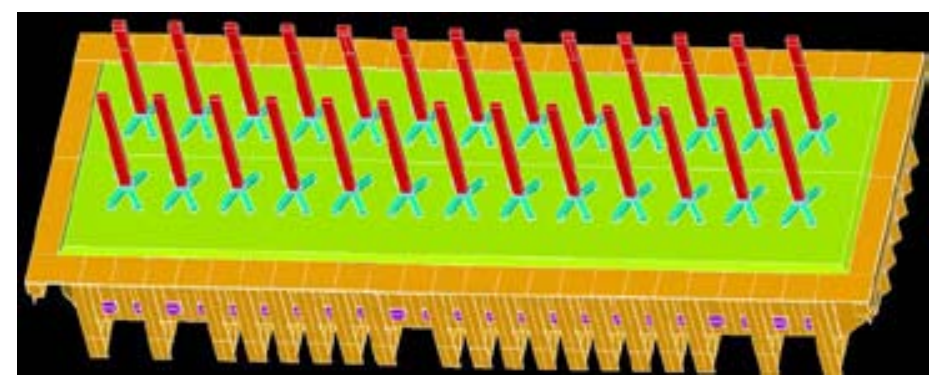

Fig. 4. 3D model of 1'000'000 A cell

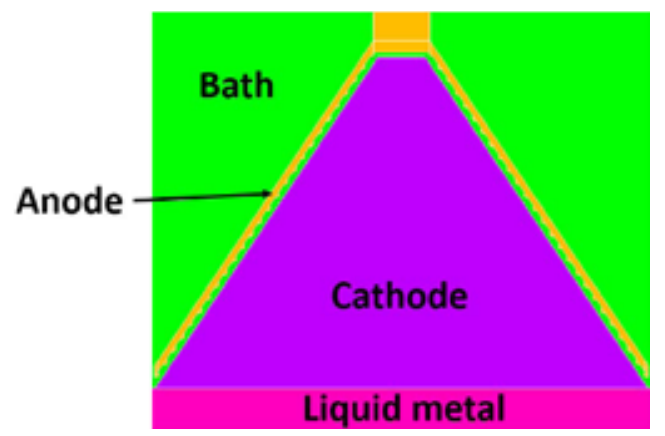

Fig. 5. Vertical section through the cell showing $1 / 2$ of one anode

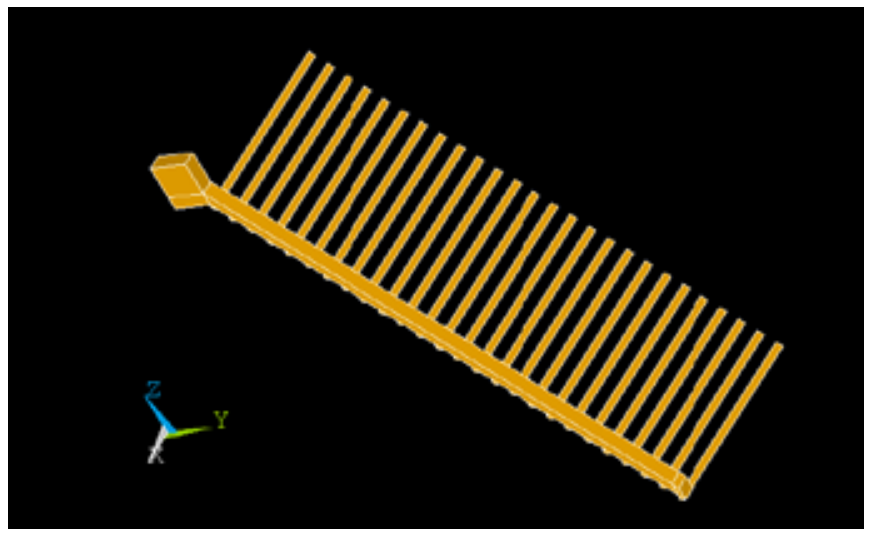

Fig. 6. Geometry of $1 / 4$ anode 
Figure 7 shows the electrical potential in the distance from the entrance of the anode to the liquid metal for $1 / 4$ of one anode. The voltage is equal to $1.013 \mathrm{~V}$ which is very much in line with the targeted voltage given in Table 3. Indeed, the ohmic voltage drop should be $0.1+0.063+0.847=1.010 \mathrm{~V}$.

The current density in the same $1 / 4$ anode is shown in Fig. 8.

Figure 9 shows the current density inside the bath. It can be observed that the average value over the surface is about $2 \mathrm{~A} / \mathrm{cm}^{2}$. In average it remains $0.865 \mathrm{~A} / \mathrm{cm}^{2}$ but is increased locally due to the "finger" geometry.

By looking locally around one anode finger (Fig. 10), one can see that the current density is varying between about $0.6 \mathrm{~A} / \mathrm{cm}^{2}$ to $2.8 \mathrm{~A} / \mathrm{cm}^{2}$ maximum. This could be improved drastically by searching for better anode shapes and would lead to even lower voltage drop. In the frame of this feasibility study it was not necessary as the cell shows already much better figures than the carbon anode cell.

\section{Conclusions}

Under the assumptions that:

- A metallic anode is available with an economical life (must not be inert forever!)

- A wettable cathode is available for draining the metal for a few years a cell can be designed with:

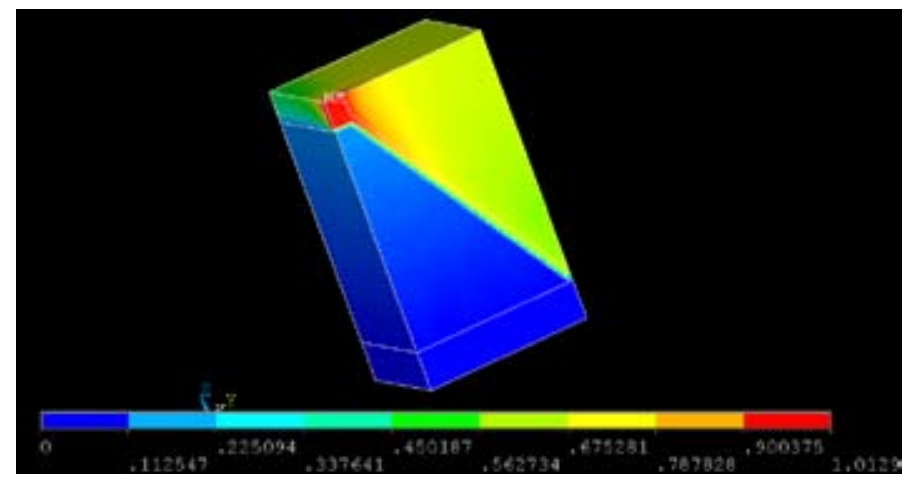

Fig. 7. Electrical potential in $1 / 4$ anode (V)

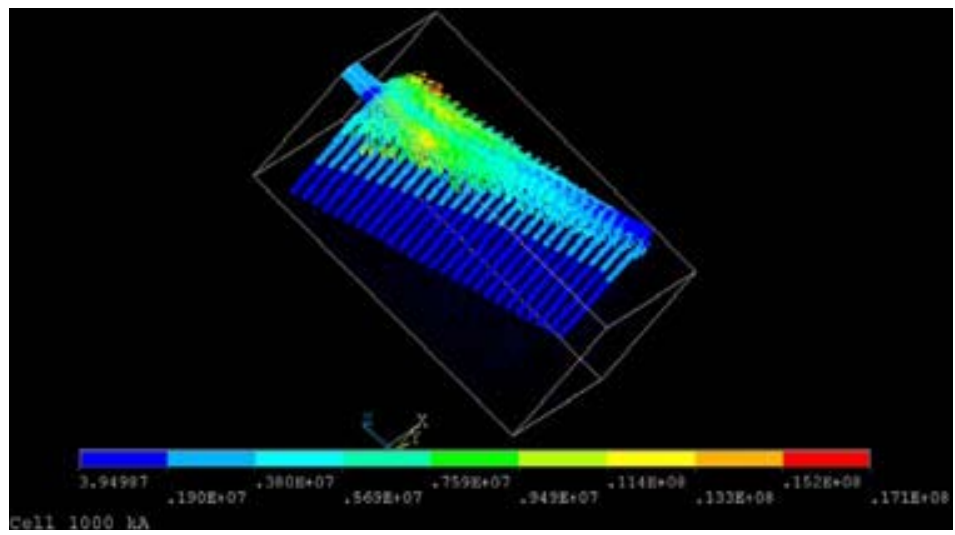

Fig. 8. Current density in $1 / 4$ anode $\left(\mathrm{A} / \mathrm{m}^{2}\right)$ 


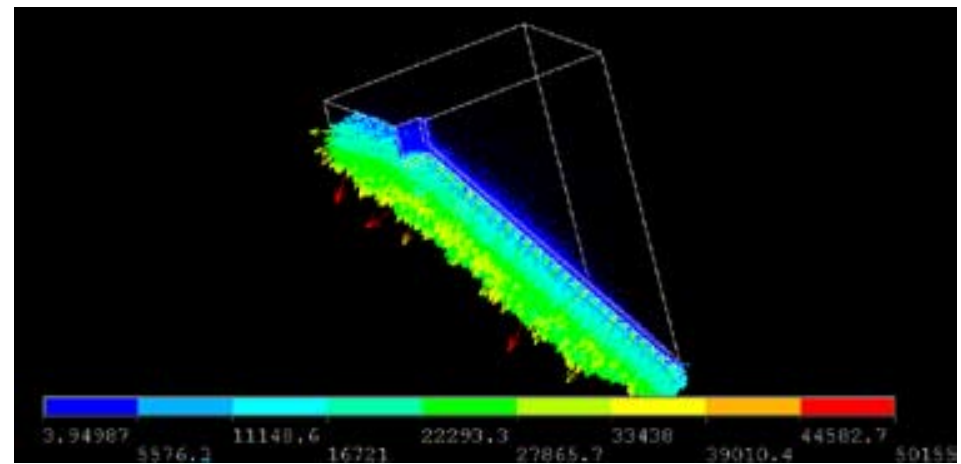

Fig. 9. Current density in $1 / 4$ area of the bath $\left(\mathrm{A} / \mathrm{m}^{2}\right)$

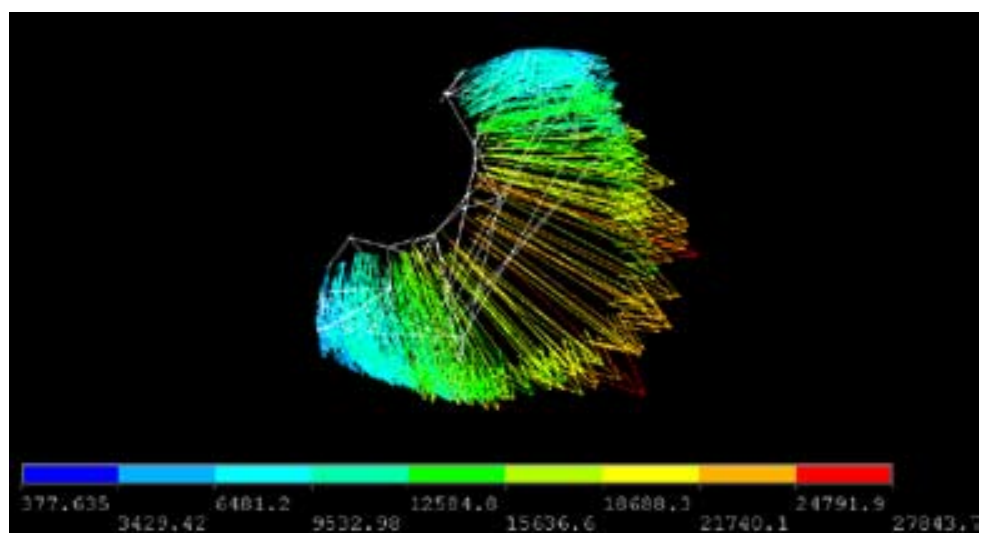

Fig. 10. Current density around one anode "finger" $\left(\mathrm{A} / \mathrm{m}^{2}\right)$

- More than double productivity than today

- Lower than $12 \mathrm{kWh} / \mathrm{kg}$ specific energy consumption

- Higher than 95\% current efficiency

- Better economical results than today's technology

In other words, the dream is not unrealistic as was demonstrated by performing thermal-electrical calculations.

\section{References}

[1] Antille J., Klinger L., Von Kaenel R., de Nora V. Modelling of a 25 kA De Nora inert metallic anode test cell, Light Metals, 2006, 391-396. 